amount is expected to rise to 85 million hoppus $\mathrm{ft}$. in 1980. Much of this is destined for pulp and chipboard and thus much attention has been directed in recent years to increasing the efficiency of their extraction. The descriptions of the various extraction methods are based on experience and on the findings of the work study section, and supporting data are given in a series of tables. The general conclusions reached are that, of the seven types of extraction compared, the double drum winch is the best for both uphill and downhill hauls. Horse extraction is good for short distances downhill but not very efficient uphill, and under some conditions the wheeled tractor may be the cheapest method. So much importance is attached to the use of the Isachsen double-drum winch that Forestry Commission Booklet No. 12 is devoted to it (Double Drum Winch Technique. By R. E. Crowther and S. Forrester. Pp. $38+8$ plates. London: H.M.S.O., 1964. 3s. net). This is a useful manual with clear explanations and good illustrations. It and its companion booklet are examples of concinnity.

\section{Royal Astronomical Society Awards}

The President and Council of the Royal Astronomical Society have made the following awards: Gold Medals, to Dr. G. M. Clemence of Yale University, in recognition of his applications of celestial mechanics to motions in the solar system and his fundamental contributions to the study of time and the system of astronomical constants; to Sir Edward Bullard of the University of Cambridge, for his pioneering work in geophysics and, in particular, his leadership in the field of studies of the geology of the ocean floor; Eddington Medal, jointly to Prof. R. V. Pound and Dr. G. A. Rebka of Harvard University, for their decisive experiment of measuring the gravitational red shift on the surface of the Earth through the methods of nuclear physics.

\section{Institute of Metals Awards}

THE Council of the Institute of Metals has announced the following medal awards: Institute of Metals (Platinum) Medal for 1965, to Prof. A. H. Cottrell, in recognition of his services to the non-ferrous metal industries; Rosenhain Medal for 1965, to Mrs. M. K. McQuillan, in recognition of her contributions in the field of physical metallurgy; W. H. A. Robertson Medal and Premium for 1964, to Mr. D. Green, for his paper entitled "An Experimental High-speed Machine for the Practical Exploitation of Hydrostatic Extrusion" published in the Journal of the Institute (November 1964).

\section{University News :}

Belfast

Dr. E. H. Frost-SMrTH, research director with Stavely Industries, Ltd., has been appointed to the chair of electrical engineering.

Birmingham

THe following appointments have been announced: Lecturer, Dr. D. A. Lihou (chemical engineering); Dr. K. C. Hooper (physiology); D. Tarin (pathology). Research Fellow, J. P. Barton (physies); C. A. T. Harnden (civil engineering); M. Landon (biochemistry); J. W. Dale (Senior Research Fellow in the Department of Experimental Pathology). The following titles have been conferred: Reader, Dr. S. A. Barker (carbohydrate chemis try) ; Dr.A.B. Foster (organic chemistry); Dr. G. J. Lawson (minerals engineering).

Dr. G. M. THUates hos been appointed to the chair of zoology as from August 1, in succession to Prof. J. E. Harris. Dr. M. P. Banton has been appointed to the newly established chair of sociology as from August 1.

Cambridge

Sir Edward Bullard, reader and head of the Department of Geodesy and Geophysics in the University of
Cambridge, has been appointed to the chair of geophysics at the University.

Lancaster

IN response to the recent appeal by the new University of Lancaster for funds to supplement its Government grants, Mullard, Ltd., has agreed to donate the sum of $£ 10,000$.

London

DR. H. R. V. ARnstein, a member of the scientific staff of the Medical Research Council, has been appointed to the chair of biochemistry tenable at King's College. Dr. G. M. Jenkins, reader in mathematical statistics at the Imperial College of Science and Technology, has been appointed to the chair of statistics tenable at Queen Mary College. The following titles have been conferred: Professor, Dr. A. Ashmore (nuclear physics). Reader, Dr. D. F. Evans (inorganic chemistry); Dr. Marie B. Hall (history of science and technology).

\section{Announcements}

THE name of the International Nickel Company (Mond), Ltd., has been changed to International Nickel, Ltd. This took effect as from January 1.

DR. VAN ZANDT WILLIAMS, president-elect of the Optical Society of America, has been appointed director of the American Institute of Physics with effect from April 1 .

DR. H. K. CAMEron, chairman of the London Section of the Society of Chemical Industry, has been awarded the Lampitt Medal for 1965 by the Council of the Society of Chemical Industry.

DR. W. Lane-Petter is relinquishing his position as director of the Laboratory Animals Centre, as from January 31,1965 , in order to become director of Carworth Europe, a subsidiary of Carworth Laboratories (U.S.A.).

Mr. F. N. SutherLaND, deputy chairman and managing director of The Marconi Co., Ltd., has been appointed president of the Council of the Television Society as from January 1. Mr. Sutherland succeeds Sir Robert Fraser, who has held office for the past two years.

Mr. F. D. OUTRIDGE was appointed director of the Council of the Scientific Instrument Manufacturers' Association, at their January meeting. He succeeds Capt. R. A. Villiers. Mr. Outridge joined the Association in 1961, and was appointed acting director in July 1964.

THE seventh session of the Welsh Soils Discussion Group on "Physical Aspects of Soil Fertility" will be held in Bangor on February 10. Further information can be obtained from Dr. A. H. Charles, Welsh Plant Breeding Station, Gogerddan, near Aberystwyth.

A SERIES of six evening lectures under the general title "Science, Industry and the State," organized by the Office of Health Economics, will be held at the Royal Society of Health during the first three months of 1965. Further information and forms of application for tickets can be obtained from the Director's Secretary, Office of Health Economics, 62 Brompton Road, London, S.W.3.

Trree lectures on "The Scientific Basis of Dentistry", arranged by the British Postgraduate Medical Federation, will be held at the Royal College of Surgeons on February 10, February 24 and March 10. The lectures, which are designed for research workers and specialists in training, will be as follows: "Science in Dentistry", by Prof. D. J. Anderson; "Electron Microscope Autoradiography", by Dr. S. R. Pelc; "Histochemical Techniques in the Study of the Cellular Biology of Dental Tissues", by Dr. A. R. Ten Cate. Further information can be obtained from the British Postgraduate Medical Federation, 18 Guilford Street, London, W.C.1. 